\title{
Syntheses and Characterization of Two Novel Copper(II) Malonate Complexes Functionalized with 3,3'-Bis(pyrazolyl)pentane and $4,4^{\prime}$-Trimethylenedipyridine
}

\author{
Alvine Loris Djoumbissie ${ }^{1}$, Alain Clovis Tayo Djampouo무, Tanyi Rogers Fomuta1, \\ Giscard Doungmo ${ }^{2}$, Golngar Djimassingar ${ }^{1,3}$, Alain Charly Tagne Kuate ${ }^{1^{*}}\left(\mathbb{D}\right.$, Jean Ngoune ${ }^{1^{*}} \mathbb{C}$ \\ ${ }^{1}$ Department of Chemistry, University of Dschang, Dschang, Cameroon \\ ${ }^{2}$ Institute of Inorganic Chemistry, Christian-Albrechts University of Kiel, Kiel, Germany \\ ${ }^{3}$ Department of Chemistry, Mongo Polytechnique University Institute (IUPM), Mongo, Chad \\ Email: *alctagne@gmail.com, *jean.ngoune@univ-dschang.org, *jeangoune@yahoo.com
}

How to cite this paper: Djoumbissie, A.L., Djampouo, A.C.T., Fomuta, T.R., Doungmo, G., Djimassingar, G., Kuate, A.C.T. and Ngoune, J. (2021) Syntheses and Characterization of Two Novel Copper(II) Malonate Complexes Functionalized with 3,3'-Bis(pyrazolyl)pentane and 4,4'-Trimethylenedipyridine. Open Journal of Inorganic Chemistry, 11, 43-53. https://doi.org/10.4236/ojic.2021.112003

Received: March 3, 2021

Accepted: April 27, 2021

Published: April 30, 2021

Copyright () 2021 by author(s) and Scientific Research Publishing Inc. This work is licensed under the Creative Commons Attribution International License (CC BY 4.0)

http://creativecommons.org/licenses/by/4.0/

\begin{abstract}
Two novel copper complexes $(1,2)$ with $\mathrm{N}, \mathrm{O}$-donor ligands were synthesized by reaction of copper(II) malonates with 3,3'-bis(pyrazolyl)pentane and $4,4^{\prime}$-trimethylenedipyridine in methanol at moderate temperature. These compounds were characterized by elemental analysis, UV-VIS, IR spectroscopies and powder X-ray diffraction analyses. Compound (1) melts at higher temperature $\left(202^{\circ} \mathrm{C}\right)$ than compound $(2)\left(100^{\circ} \mathrm{C}\right)$. The IR spectra showed typical vibrations related to $\mathrm{C}=\mathrm{N}$ and $\mathrm{C}=\mathrm{C}$, characteristic of pyrazolyl and pyridine ligands.
\end{abstract}

\section{Keywords}

Copper, Malonate, 3,3'-Bis(pyrazolyl)pentane, 4,4'-Trimethylenedipyridine, UV-Vis, IR, Powder X-Ray Diffraction

\section{Introduction}

The coordination chemistry of copper is very rich because of its biological roles [1] [2] [3] and diverse practical applications as photosensitizers, triplet emitters, catalysts, fungicides, and pesticides [4] [5]. Complexes of copper(II) with $\mathrm{N}$ - and O-donor ligands are well known. Copper(II) carboxylate complexes have important properties in various areas and have been extensively studied [6]. They are known to form different kinds of structures even with the same ligand. The reasons for this diverse nature are due to the basic nature of ligands, steric factor, 
precursors, and solvents. It was found that the malonate anion can display various coordination modes with $3 d$ transition metal ions. The coordination modes encountered are: bidentate, bidentate/monodentate, bidentate/bis(monodentate), and bidentate/bis(monodentate)/ $\mu$-oxo [7]. Although many complexes containing mixed malonate and nitrogen-donor ligands have been synthesized and characterized, complexes containing both the malonate ion (mal) and

3,3'-bis(pyrazolyl)pentane ligands have not yet been reported. However, complexes with both malonate and 4,4'-trimethylenedipyridine (TMDP) ligand have already been reported but to a lesser extent. To the best of our knowledge, the only reported compound with mixed malonate ion/4,4'-trimethylenedipyridine ligands is

$\left\{\left[\mathrm{Cu}\left(\mathrm{OH}_{2}\right)(\mathrm{TMDP})_{2}\right]\left[\mathrm{Cu}(\mathrm{mal})_{2}(\mathrm{TMDP})\right]\left[\mathrm{Cu}(\mathrm{mal})\left(\mathrm{OH}_{2}\right)(\mathrm{TMDP})\right] 12 \mathrm{H}_{2} \mathrm{O}\right\} \mathrm{n}$ [8]. This complex was obtained by slow diffusion method using copper carbonate in a 1:1 metal-ligand ratio.

In order to enlarge this family of compounds and to investigate the structural variations, the change in methods of syntheses and the change in the functionalizing ligands may have influence on the structural and electronic properties of the materials, as well as their effects on the applications of the compounds. We report herein, the preparation of two copper(II) malonate compounds functionalized with 3,3'-bis(pyrazolyl)pentane and 4,4'-trimethylenedipyridine(TMDP) ligands by slow evaporation method.

\section{Materials and Methods}

\subsection{Materials}

All chemicals were purchased from Aldrich and used as received without further purification. 3,3'-bis(pyrazolyl)pentane, copper(II) malonate and water were of analytical grade. Elemental analysis was performed using a Euro Vector CHNS-O element analyzer. FT-IR spectra were recorded using a Perkin-Elmer FT-IR 100 spectrometer. The melting point of the compound was obtained using an SMP3 Stuart Scientific melting point apparatus while UV-vis spectrophotometer model GENESYS 10S was employed to record the electronic spectra of the investigated compounds. Powder X-rays diffraction was performed using STOE Stadi-p X-ray powder diffractometer with $\mathrm{Cu}$ Kal radiation $(\lambda=1.54056 \AA$; $\mathrm{Ge}$ monochromator; flat samples) in transmission geometry.

\subsection{Synthesis of Compound (1)}

Blue crystal of copper(II) malonate $(172.0 \mathrm{mg}, 1.0 \mathrm{mmol}$ ) were dissolved in methanol-distilled water mixture $(10 \mathrm{~mL}-5 \mathrm{~mL})$ at $50^{\circ} \mathrm{C}$. To the blue solution obtained was added dropwise, colorless methanol-distilled water $(5 \mathrm{~mL}-10 \mathrm{~mL})$ solution of 3,3'-bis(pyrazolyl)pentane $(204.0 \mathrm{mg}, 2.0 \mathrm{mmol})$. The mixture was stirred for $1 \mathrm{~h}$ and the blue solution obtained was filtered. The filtrate was left to slowly evaporate at room temperature for several days. The obtained product was washed with a methanol-distilled water mixture and then dried at air, giving 
blue crystals of (1), in $66.5 \%\left(250 \mathrm{mg}\right.$ ) yield. $\mathrm{Mp}: 202^{\circ} \mathrm{C}$, Anal. Calc. (\%) for $\mathrm{C}_{28} \mathrm{H}_{46} \mathrm{Cu}_{2} \mathrm{~N}_{8} \mathrm{O}_{13}$ : C 40.48; $\mathrm{H}$ 5.70; $\mathrm{N}$ 13.49. Found (\%): C 39.72; $\mathrm{H}$ 5.77; $\mathrm{N} 13.68$. FT-IR (v, $\left.\mathrm{cm}^{-1}\right)$ : $3414.1(\mathrm{br}), 3213.6(\mathrm{br}), 1578.1(\mathrm{vs}), 1434.1(\mathrm{w}), 1340.9(\mathrm{w})$, $1221.2(\mathrm{w}), 1064.6(\mathrm{w}), 763.3(\mathrm{~m}), 719.4(\mathrm{~m}) \mathrm{cm}^{-1}$.

\subsection{Synthesis of Compound (2)}

Similarly, compound (2) was synthesized by mixing copper(II) malonate (150 $\mathrm{mg}, 0.74 \mathrm{mmol}$ ) and 4,4'-trimethylenedipyridine $(295 \mathrm{mg}, 1.48 \mathrm{mmol})$ in a methanol-distilled water solvent mixture. The reaction mixture was heated to $50^{\circ} \mathrm{C}$ for one hour with constant stirring. The resultant mother liquor was then filtered, and left unperturbed for several days at room temperature for slow evaporation. The resulting solid was washed with distilled water, then dried at air, leaving dark blue platelets of compound (2) in $65 \%\left(289 \mathrm{mg}\right.$ ) yield. $\mathrm{Mp}: 100^{\circ} \mathrm{C}$ Anal. Calc. (\%) for $\mathrm{C}_{32} \mathrm{H}_{36} \mathrm{CuN}_{4} \mathrm{O}_{9}$. C 56.17; $\mathrm{H}$ 5.30; $\mathrm{N}$ 8.19. Found (\%): $\mathrm{C} 56.4 ; \mathrm{H}$ 6.64; N 9.51. FT-IR (v, $\left.\mathrm{cm}^{-1}\right): 3675.0$ (vw), 1613.0 (vs), 1573.9 (s), 1427.7(s), $1335.4(\mathrm{w}), 1225.3(\mathrm{w}), 800.0(\mathrm{~m}), 700.1(\mathrm{~m}) \mathrm{cm}^{-1}$

\section{Results and Discussion}

\subsection{Synthetic Aspect}

Synthesis of Compound (1): Compound (1) was obtained by mixing copper(II) malonate, prepared from malonic acid and copper(II) nitrate, with $3,3^{\prime}$-bis(pyrazolyl)pentane in methanol-distilled water mixture at $50^{\circ} \mathrm{C}$ (Scheme 1). The solution obtained was left for slow evaporation and blue crystalline solid of (1) was isolated.

$$
\mathrm{Cu}\left(\mathrm{O}_{4} \mathrm{C}_{3} \mathrm{H}_{2}\right)_{4} \cdot 2 \mathrm{H}_{2} \mathrm{O}+2 \mathrm{C}_{11} \mathrm{H}_{16} \mathrm{~N}_{4} \stackrel{\mathrm{MeOH} / \mathrm{H}_{2} \mathrm{O}}{50^{\circ} \mathrm{C}}\left[\left(\mathrm{Cu}\left(\mathrm{N}_{4} \mathrm{C}_{11} \mathrm{H}_{16}\right)_{2}\left(\mathrm{O}_{4} \mathrm{C}_{3} \mathrm{H}_{2}\right)_{2}\left(\mathrm{OH}_{2}\right)\right)_{5}\right]
$$

Scheme 1

Compound (1) appeared as blue crystals that are soluble in methanol, ethanol, dimethylformamide and dimethyl sulfoxide and insoluble in water, dichloromethane, acetonitrile and are stable in air.

Synthesis of Compound (2): Compound (2) was obtained by mixing copper(II) malonate, prepared from malonic acid and copper(II) nitrate with $4,4^{\prime}$-trimethylenedipyridine in methanol-distilled water solution mixture at $50^{\circ} \mathrm{C}$ (Scheme 2). After slow evaporation of the solvent mixture, a dark blue crystalline solid of the compound was isolated in good yield.

$$
\mathrm{Cu}\left(\mathrm{O}_{4} \mathrm{C}_{3} \mathrm{H}_{2}\right)_{4} \cdot 2 \mathrm{H}_{2} \mathrm{O}+2 \mathrm{C}_{13} \mathrm{H}_{14} \mathrm{~N}_{2} \underset{50^{\circ} \mathrm{C}}{\stackrel{\mathrm{MeO} / \mathrm{H}_{2} \mathrm{O}}{\longrightarrow}}\left[\left(\mathrm{Cu}\left(\mathrm{N}_{2} \mathrm{C}_{13} \mathrm{H}_{14}\right)_{2}\left(\mathrm{O}_{4} \mathrm{C}_{3} \mathrm{H}_{2}\right)_{2}\right)\right] \cdot\left(\mathrm{H}_{2} \mathrm{O}\right)
$$

Scheme 2

This air stable material is soluble in dimethylformamide and dimethylsulfoxide and insoluble in water, dichloromethane, acetonitrile and methylcyanate.

\subsection{Infrared Spectroscopy}

The FT-IR spectrum of compound (1) (Figure 1(a)) shows the presence of the 
pyrazolyl ligand and carboxylate ion used in the synthesis of the compound, through the typical vibrations of pyrazolyl ring and carboxylate groups. The presence of $\mathrm{O}-\mathrm{H}$ characteristic absorption band around $3414 \mathrm{~cm}^{-1}$ is an indication that the compound contains water molecules. The very strong absorption band around $1578 \mathrm{~cm}^{-1}$ can be attributed to the valence vibrations of the $\mathrm{C}=\mathrm{N}$ of the pyrazole unit [9]. This band which usually appears at $1595 \mathrm{~cm}^{-1}$ has been shifted to $1578 \mathrm{~cm}^{-1}$ suggesting the coordination of 3,3'-bis(pyrazolyl)pentane ligand to the metal ion. Similar displacements were observed in the reported [ $\left.\mathrm{Ag}\left(\mathrm{N}_{2} \mathrm{C}_{11} \mathrm{H}_{10}\right)_{2}\right] \mathrm{NO}_{3}$ (where $\mathrm{N}_{2} \mathrm{C}_{11} \mathrm{H}_{10}=4,5$-dihydro- $1 H$-benzo [g]indazole) [10]. The weak band at $1340 \mathrm{~cm}^{-1}$ can be attributed to the vibrations of the $\mathrm{C}=\mathrm{O}$ group of carboxylates. Between $1300 \mathrm{~cm}^{-1}$ and $750 \mathrm{~cm}^{-1}$, are the deformation vibrations of the pyrazole rings and those of aliphatic $\mathrm{C}-\mathrm{H}$ groups present in the ligand.

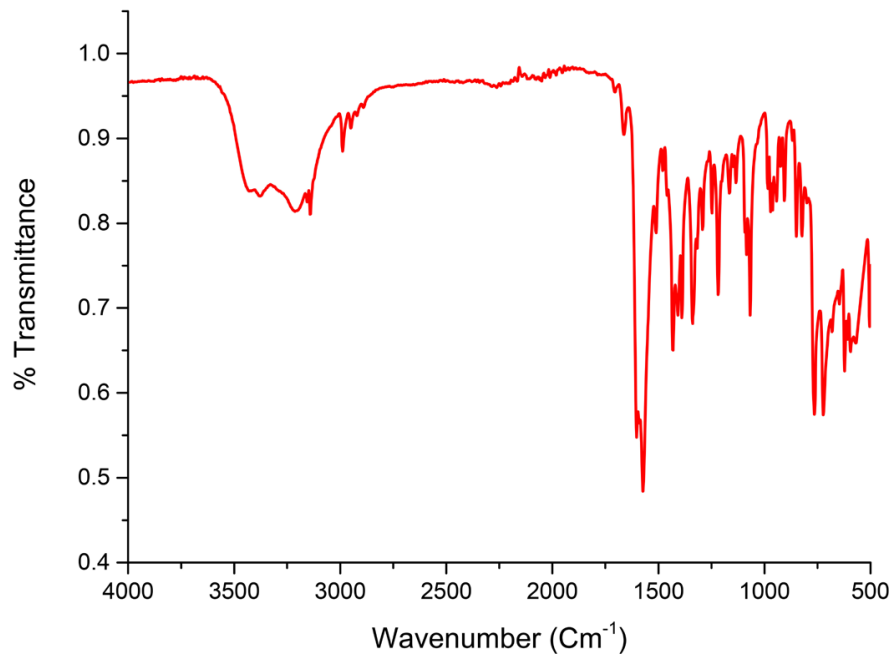

(a)

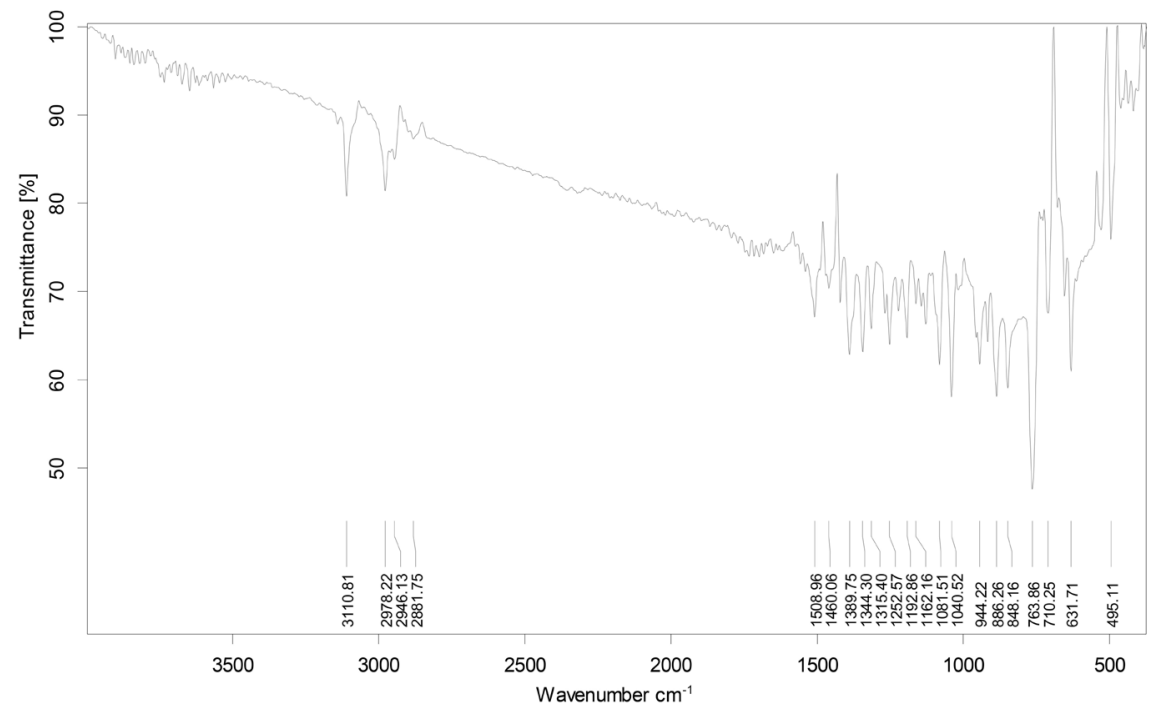

(b)

Figure 1. FT-IR spectrum of compound $(1,(a))$ and of the free ligand (3,3'-bis(pyrazolyl)pentane, (b)). 
On the other hand, the FT-IR spectrum of compound (2) (Figure 2(a)) displays very weak absorption bands at $3675 \mathrm{~cm}^{-1}$ which could be attributed to the $\mathrm{O}-\mathrm{H}$ vibration, indicating the presence of water in the material. The very strong band appearing between $1620 \mathrm{~cm}^{-1}$ and $1600 \mathrm{~cm}^{-1}$ is assignable to the stretching vibrations of the azomethine, $\mathrm{C}=\mathrm{N}$ functions [11] [12]. This vibration is similar to that reported for [ $\left.\mathrm{Zn}(\mathrm{SCN})_{2}(\mathrm{TMDP})\right]$ [13]. Compound (2) shows two strong absorption bands at $1574 \mathrm{~cm}^{-1}$ and $1428 \mathrm{~cm}^{-1}$ due to the asymmetric and symmetric vibration of the carboxylate group of the malonate anion. The $146 \mathrm{~cm}^{-1}$ difference between the asymmetric and symmetric vibrations of the carboxylate indicates that the carboxylate group forms a chelating coordination mode to the copper(II) ion. Meanwhile, the deformation oscillations of the aromatic $\mathrm{C}-\mathrm{H}$ groups occur between $856 \mathrm{~cm}^{-1}$ and $624 \mathrm{~cm}^{-1}$.

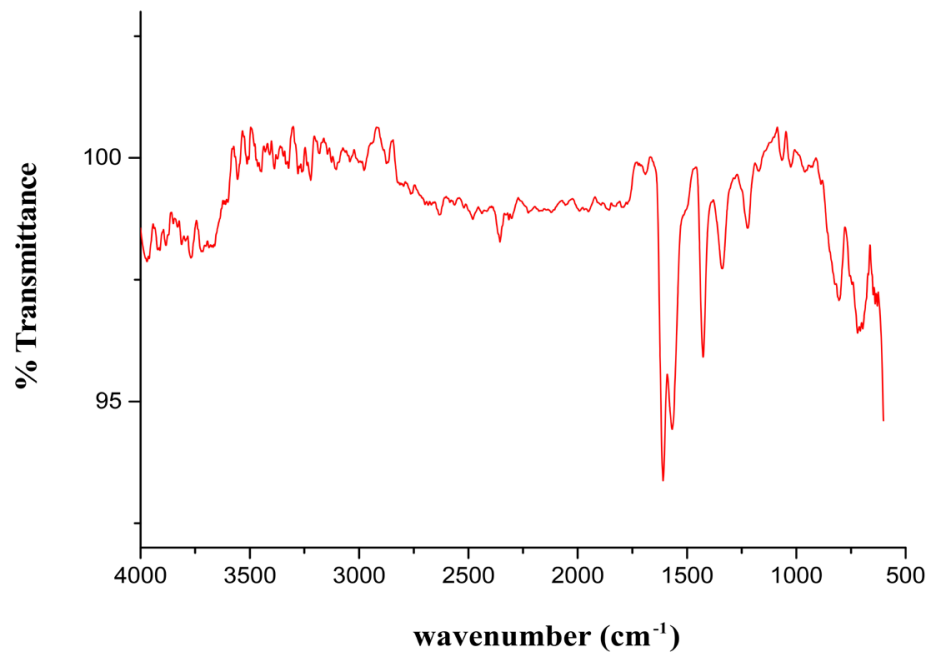

(a)

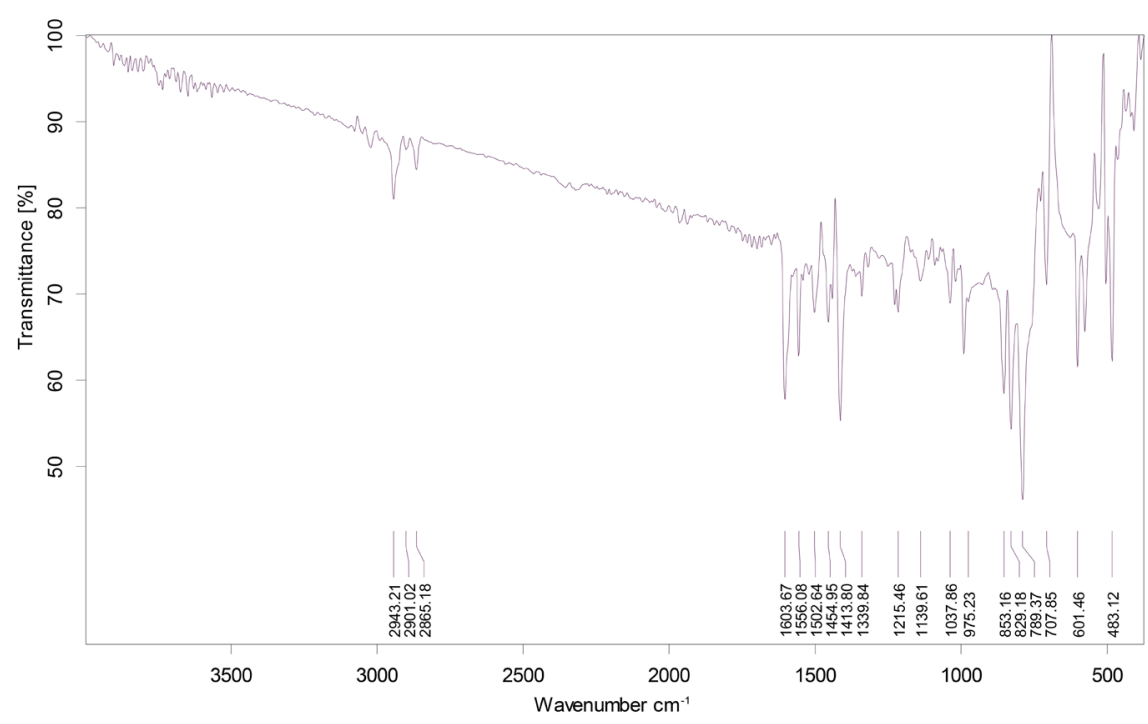

(b)

Figure 2. FT-IR spectrum of compound $(2,(a))$ and of the free ligand (4,4'-trimethylenedipyridine, (b)). 
These analyses confirm the functionalization of copper(II) malonate with 3,3'-bis(pyrazolyl)pentane and 4,4'-trimethylenedipyridine.

\subsection{UV-VIS Spectroscopy}

The electronic absorption spectrum of (1) (Figure 3) was recorded in DMSO solvent at a range of $200-800 \mathrm{~nm}$. An intense band observed at $268 \mathrm{~nm}$ was assigned to the intra-ligand $\pi \rightarrow \pi^{*}$ and $n \rightarrow \pi^{*}$ electronic transitions for aromatic rings of 3,3'-bis(pyrazolyl)pentane and $\mathrm{C}=\mathrm{O}$ group of malonate anion. This value is similar to those observed by Afifa Mushtaq and co-workers, at $270 \mathrm{~nm}$ for a copper(II) carboxylate compound, functionalized using bipyridine [14]. No d-d transitions and charge transfer were observed and this may be due to the weakness of the bands [15].

Figure 4 shows the UV-Vis absorption spectrum of compound (2). This figure indicates a single band in the visible region, characteristic of copper(II)

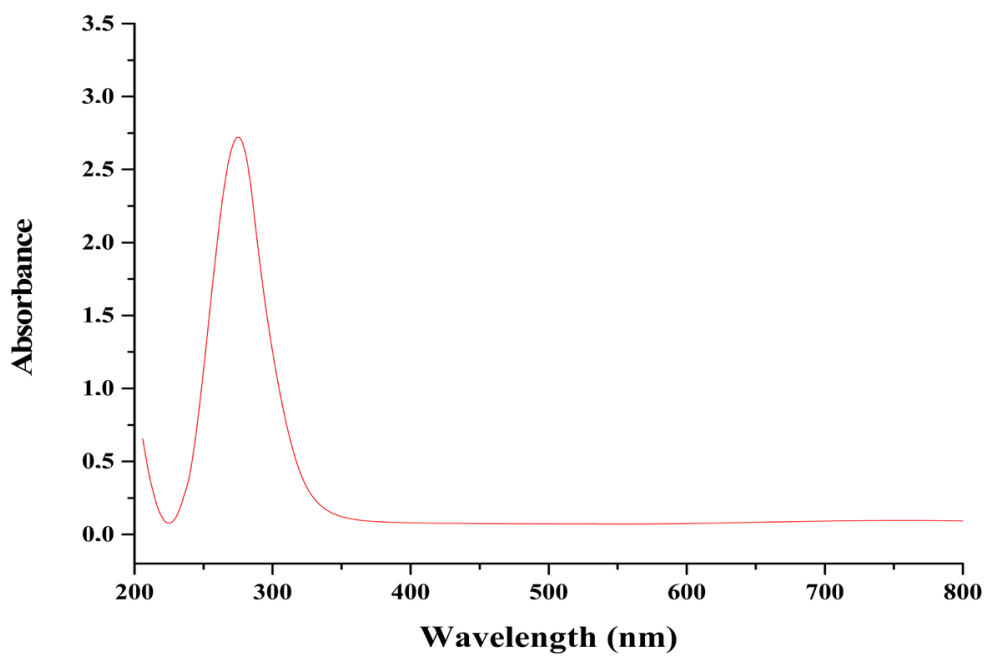

Figure 3. UV-VIS spectrum of compound (1).

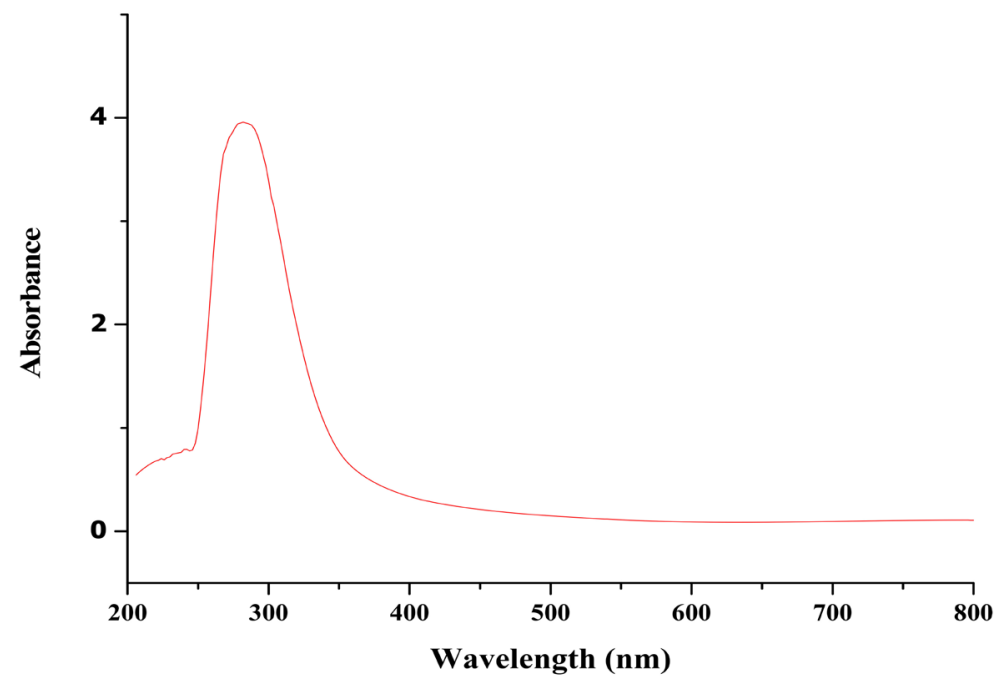

Figure 4. UV-VIS spectrum of compound (2). 
compounds. This intense band at $286 \mathrm{~nm}$ corresponds to the intra-ligand $\pi \rightarrow \pi^{\star}$ and $\mathrm{n} \rightarrow \pi^{*}$ electronic transitions which can be attributed to the pyridine moiety of the 4,4'-trimethylenedipyridine ligand and the $\mathrm{C}=\mathrm{O}$ group of malonic acid. This wavelength can also be assigned to the ligand metal charge transfer transition. It is similar to those observed by Sarath and Yamuna for cobalt functionalized with 4,4'-trimethylenedipyridine [16]. This confirms the fact that the compound contains 4,4'-trimethylenedipyridine in its coordination sphere. No d-d transitions were also observed [15].

\subsection{Powder X-Rays Diffraction}

The diffractograms obtained from the powder X-ray analysis of compound (1) and (2) in the range $5^{\circ}$ to $70^{\circ}$ are shown in Figure 5 and Figure 6. The sharp Bragg peaks of good intensities found on the spectra indicate a high level of

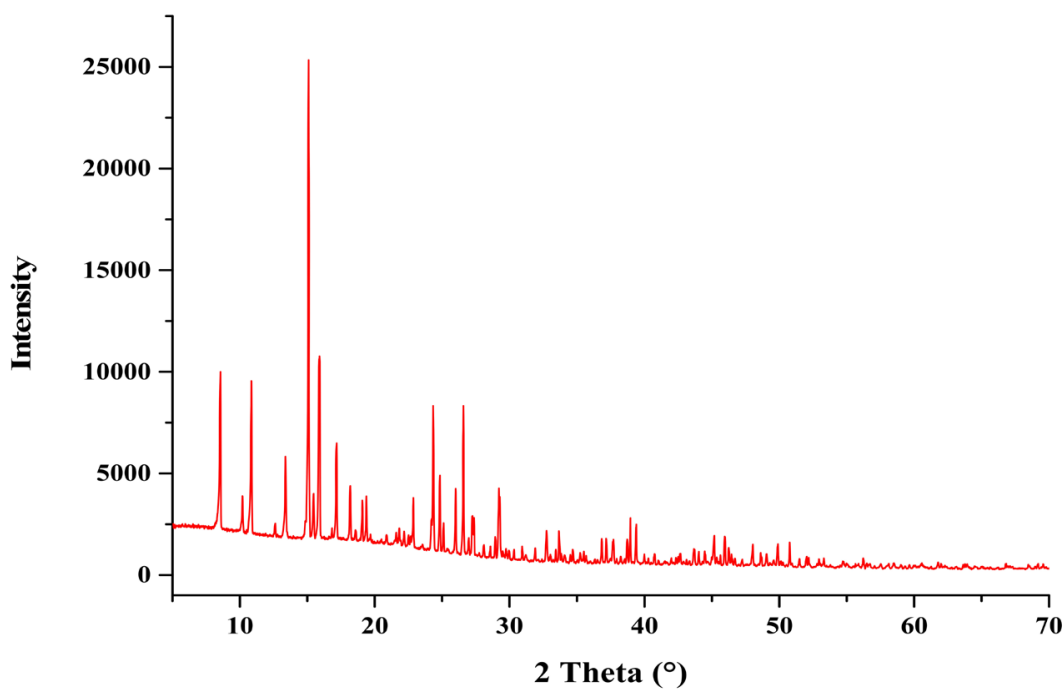

Figure 5. Powder X-ray diffractogram of compound (1).

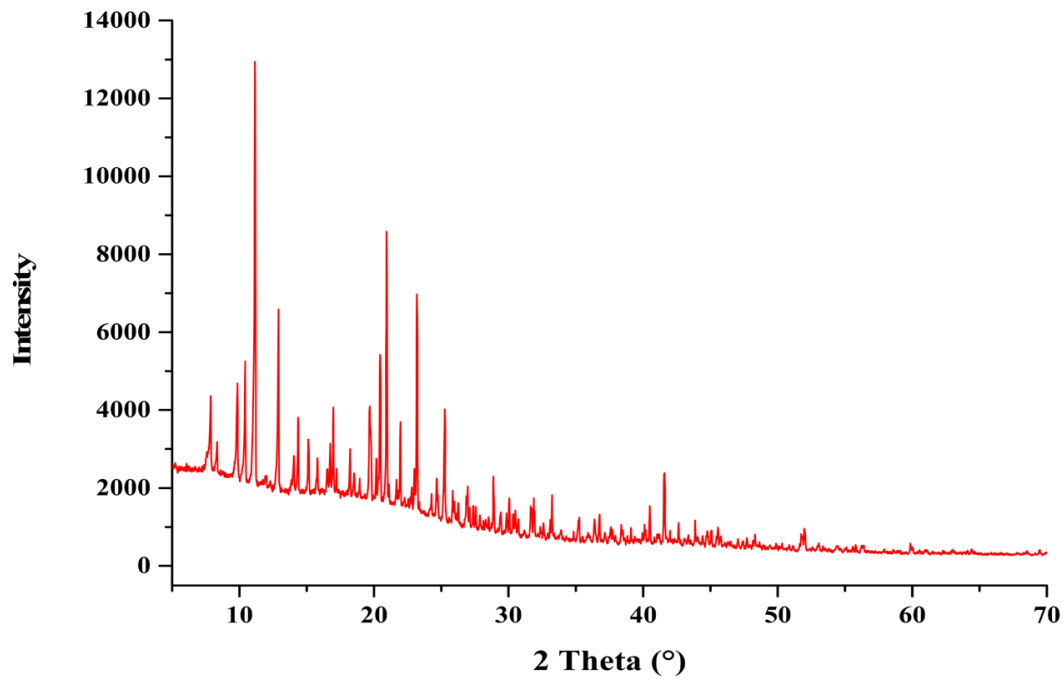

Figure 6. Powder X-ray diffractogram of compound (2). 
crystallinity of the materials. The low reflection rate (or reduced number of reflections) did not permit the unravelling of the unit cell parameters and space group of the compounds. However, the non-superposition of the PXRD patterns of compounds (1) and (2) with that of copper(II) malonate, as shown in Figure 7 and Figure 8 respectively, indicates the formation of new compounds and confirms the functionalization of copper(II) malonate by 3,3'-bis(pyrazolyl) pentane in compound (1) and 4,4'-trimethylenedipyridine in compound (2).

The results obtained from various analytical techniques might indicate, with caution, the structures depicted in Figure 9 for the newly functionalized coordination compounds (1) and (2). However, these structures shall be confirmed in our future publication after recrystallization of the compounds and single crystal X-ray diffraction analysis results are made available.

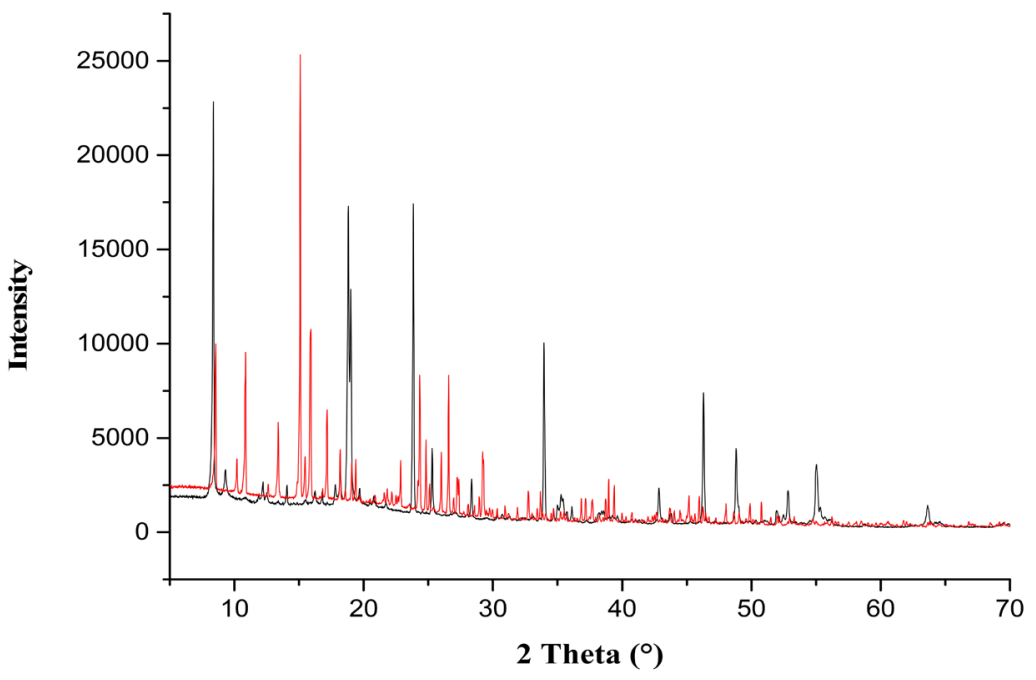

Figure 7. Powder diffractogram of copper(II) malonate (black) and of compound (1) (red).

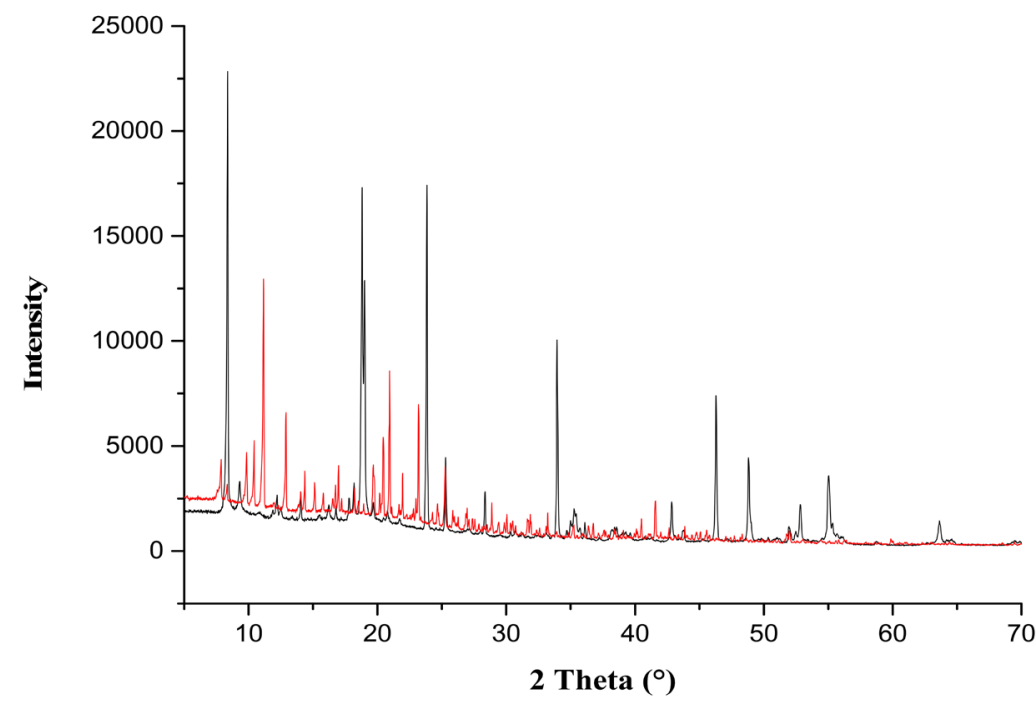

Figure 8. Powder diffractogram of copper(II) malonate (black) and of compound (2) (red). 


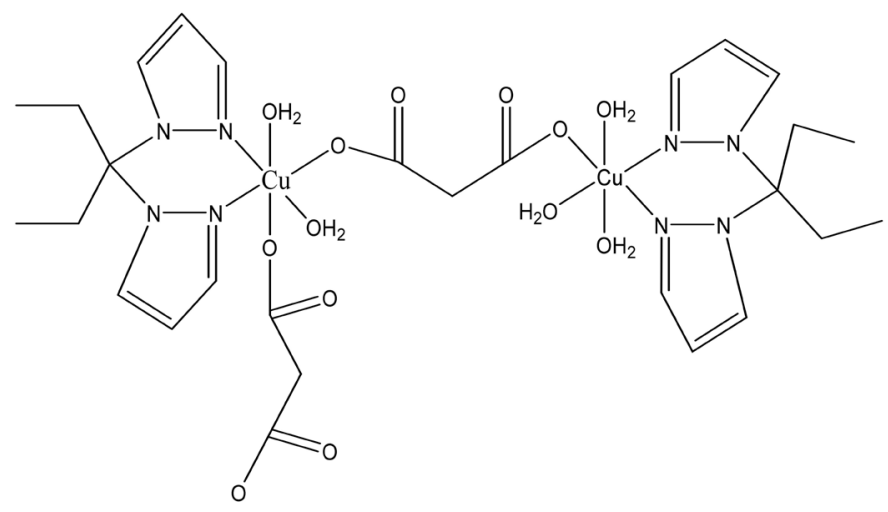

(1)

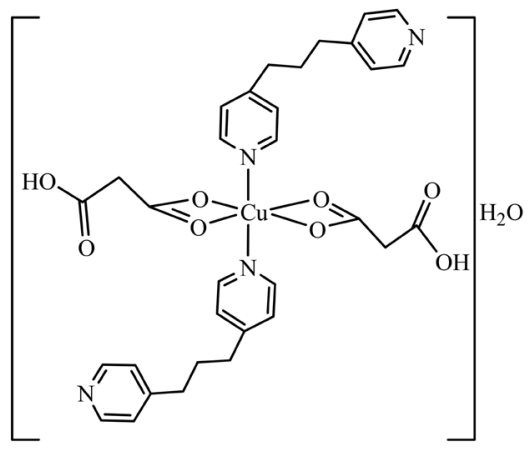

(2)

Figure 9. Proposed structures of compound (1) and compound (2).

\section{Conclusion}

In this work, two copper(II) coordination compounds based on malonate and either 3,3'-bis(pyrazolyl)pentane (1) or 4,4'-trimethylenedipyridine (2) have been reported. The compounds were analyzed using elemental analysis, UV-VIS, IR spectroscopy and powder X-rays diffraction. The IR spectroscopy indicates stretching frequencies related to the ligands. The proposed structures of (1) and (2) might agree with experimental results, but a full confirmation of these structures shall be made available in subsequent publications. Furthermore, an investigation of the structural variations the change in method of synthesis and the effects of change of functionalizing ligands may impact some properties of the compounds, including their applications which are also yet to be studied.

\section{Acknowledgements}

The authors are grateful for the "allocation spéciale pour la modernisation de la recherche universitaire" from the Ministry of Higher Education (Cameroon).

\section{Conflicts of Interest}

The authors declare no conflicts of interest regarding the publication of this paper. 


\section{References}

[1] Holm, R.H., Kennepohl, P. and Solomon, E.I. (1996) Structural and Functional Aspects of Metal Sites in Biology. Chemical Review, 96, 2239-2314.

https://doi.org/10.1021/cr9500390

[2] Worrall, J.A.R., Machczynski, M.C., Keijser, B.J.F., di Rocco, G., Ceola, S., Ubbink, M., Vijgenboom, E. and Canters, G.W. (2006) Spectroscopic Characterization of a High-Potential Lipo-Cupredoxin Found in Streptomyces coelicolor. Journal of American Chemical Society, 128, 14579-14589. https://doi.org/10.1021/ja064112n

[3] Rosenzweig, A.C. (2001) Copper Delivery by Metallochaperone Proteins. Accounts of Chemical Research, 34, 119-128.

[4] Conry, R.R. (2005) Copper: Inorganic \& Coordination Chemistry. In: Conry, R.R. and Karlin, K.D., Eds., Encyclopedia of Inorganic Chemistry, 1st Edition, John Wiley \& Sons, Inc., Hoboken, 1-19. https://doi.org/10.1002/0470862106.ia052

[5] Liu, Y., Yiu, S.C., Ho, C.L. and Wong, W.Y. (2018) Recent Advances in Copper Complexes for Electrical/Light Energy Conversion. Coordination Chemistry Reviews, 375, 514-557. https://doi.org/10.1016/j.ccr.2018.05.010

[6] Jenniefer, S.J. and Muthiah, P.T. (2013) Synthesis, Characterization and X-Ray Structural Studies of Four Copper (II) Complexes Containing Dinuclear Paddle Wheel Structures. Chemistry Central Journal, 7, Article No. 35. https://doi.org/10.1186/1752-153X-8-42

[7] Delgado, F.S., Jimenez, L.A., Lorenzo-Luis, P., Pasan, J., Fabelo, O., Canadillas-Delgado, L., Lloret, F., Julve, M. and Ruiz-Perez, C. (2012) Novel Malonate-Containing Coordination Compounds with Ligands Having N- and NO-Donors: Synthesis, Structures, and Magnetic Properties. Crystal Growth Design, 12, 599-614. https://doi.org/10.1021/cg200675u

[8] Stone, B.S. and LaDuca, R.L. (2014) Steric Effects on the Structure of Copper Malonate Coordination Polymers Containing 1,3-Di(4-Pyridyl)Propane. Polyhedron, 81, 542-549. https://doi.org/10.1016/j.poly.2014.07.012

[9] Nakamoto, K. (1970) Infrared Spectra of Inorganic and Coordination Compounds. 2nd Edition, Wiley-Interscience, New York.

[10] Fomuta, T.R., Djimassingar, G., Ngoune J., Ngnabeuye, N.O., Anguile, J.J. and Nenwa, J. (2017) Synthesis, Structural Characterization and DFT Studies of Silver(I) Complex Salt of Bis(4,5-dihydro-1H-benzo [g]indazole). Crystal Structure Theory and Applications, 6, 11-24. https://doi.org/10.4236/csta.2017.62002

[11] Alias, M., Kassum, H. and Shakir, C. (2014) Synthesis, Physical Characterization and Biological Evaluation of Schiff Base M(II) Complexes. Journal of the Association of Arab Universities for Basic and Applied Sciences, 15, 28-34. https://doi.org/10.1016/j.jaubas.2013.03.001

[12] Ajibade, P.A., Kolawale, G.A., O’Brien, P., Heliwell, M. and Raffery, J. (2006) Cobalt(II) Complexes of the Antibiotic Sulfadiazine, the X-Ray Single Crystal Structure of $\left[\mathrm{Co}\left(\mathrm{C}_{10} \mathrm{H}_{9} \mathrm{~N}_{4} \mathrm{O}_{2} \mathrm{~S}\right)_{2}\left(\mathrm{CH}_{3} \mathrm{OH}\right)_{2}\right]$. Inorganica Chimica Acta, 359, 3111-3116. https://doi.org/10.1016/j.ica.2006.03.030

[13] Suen, M.S., Tsai., H.A. and Wang, J.W. (2006) Synthesis and Structures of Infinite Coordination Polymers from 1,3-Bis(4-pyridyl)propane Ligand and Zinc Salts. Journal of the Chinese Chemical Society, 53, 305-312. https://doi.org/10.1002/jccs.200600038

[14] Mushtaq, A., Ali, S., Tahir, M.N., Ismail, H., Mirza, B., Saadiq, M., Haleem, M.A. and Iqbal, M. (2017) New Bioactive Heteroleptic Copper(II) Carboxylates: Struc- 
ture, Enzymatic and DNA-Binding Studies. Acta Chimica Slovenica, 64, 397-408. https://doi.org/10.17344/acsi.2017.3250

[15] Uzoukwu, N.A. (1993) Synthesis and Characterization of Cobalt(II) Complexes with Some 4-Acyl Derivatives of 1-Phenyl-3-Methylpyrazolone. Synthesis and Reactivity in Inorganic and Metal-Organic Chemistry, 23, 1087-1095.

https://doi.org/10.1080/15533179308016669

[16] Sarath, S. and Yamuna, R. (2018) Synthesis, Characterization and Liquid Crystalline Properties of 1,3-bis(4-pyridyl)propane Connected Long Alkyl Chain Dicobaloxime. Materials Today: Proceedings, 5, 16748-16755.

https://doi.org/10.1016/j.matpr.2018.06.040 